\title{
Customer Satisfaction in Hotel Services: A Case Study of Thanh Hoa Province, Vietnam
}

\author{
Quang Hieu LE ${ }^{1}$, Thanh Xuan Thi NGUYEN ${ }^{2}$, Thanh Thuy Thi LE ${ }^{3}$ \\ Received: August 01, 2020 Revised: September 06, 2020 Accepted: September 10, 2020
}

\begin{abstract}
The study examines the influence of factors on customer satisfaction in hotel services in Thanh Hoa province of Vietnam. In terms of the tangible facilities of hotels, customers appreciate the availability and the full range of equipment and additional services, as the 3-to-5-star hotels in Thanh Hoa province are almost new, built in the last five years - 7 of 13 hotels were built in 2015. In the process of measuring the effect of factors on satisfaction in hotel services there, the researchers conducted exploratory factor analysis, reliability test, correlation and regression to confirm the relationships of factors. Based on a survey of 380 respondents, the test results showed that the proposed factors have positive impacts on consumer satisfaction; they are: perceived quality (including intangible and tangible elements), brand image, perceived value, and customer relationship management. In particular, intangible elements have the strongest influence on customer satisfaction, followed by tangible elements, brand image, perceived value, and finally, customer relationship management. In addition, the study found that foreigners and higher education customers tend to be more satisfied by the hotels than other groups, which helps to suggest important and appropriate solutions for hotel managers in Thanh Hoa province.
\end{abstract}

Keywords: Customer Satisfaction, Service Quality, Hotels, Thanh Hoa Province

JEL Classification Code: M10, M30, M31, Z30

\section{Introduction}

Thanh Hoa province is likened to a "miniature Vietnam", with all kinds of topography and ecosystems: midland - mountainous, delta and coastal areas. It has rich and diversified natural resources located on the transport axis connecting the North and the Central regions. According to the Tourism Development Strategy of Thanh Hoa Province to 2025 , with a vision to 2030 , Thanh Hoa will become one

${ }^{1}$ First Author and Corresponding Author. Dean, Faculty of Economics and Business Administration, Hong Duc University, Vietnam [Postal Address: No 565, Quang Trung Street, Dong Ve Ward, Thanh Hoa City, Thanh Hoa Province, 40000-42000, Vietnam] Email: lequanghieu@hdu.edu.vn

${ }^{2}$ Lecturer, Faculty of Economics and Business Administration, Hong Duc University, Vietnam. Email: nguyenthithanhxuan@hdu.edu.vn

${ }^{3}$ Lecturer, Faculty of Economics and Business Administration, Hong

Duc University, Vietnam. Email: Ithanhthuy@hdu.edu.vn

(c) Copyright: The Author(s)

This is an Open Access article distributed under the terms of the Creative Commons Attribution Non-Commercial License (https://creativecommons.org/licenses/by-nc/4.0/) which permits unrestricted non-commercial use, distribution, and reproduction in any medium, provided the original work is properly cited. of the key tourist development points of the country. In 2019, the province welcomed 9,655,000 visitors, an increase of $17.0 \%$ compared to 2018 , reaching $101.6 \%$ of the plan in 2019. Total tourism revenue reached VND14,526 billion, an increase of $37 \%$ compared to 2018 ; served $17,905,000$ days of guests, an increase of $19.2 \%$ compared to 2018 . An impressive highlight of Thanh Hoa tourism in the past year was that the number of international visitors increased sharply with 300,450 , an increase of $30.5 \%$ compared to 2018. Community tourism destinations in Ba Thuoc, Quan Hoa, Lang Chanh and Cam Thuy districts are the areas that attract the most international visitors in the province with a variety of products and tours.

In tourism industry, accommodation is one of the most basic needs of travelers. At the same time, this is also an important criterion to make a complete tourism product. Thanh Hoa currently has 870 tourist accommodation establishments, totaling 30,000 rooms, with relatively diverse types of accommodation including high-class accommodation such as resort hotels, tourist apartments, and tourist villas. At the same time, there are also many hotels and motels that meet the standards to suit the needs of many customer segments. This is a positive number, reflecting the 
size and capacity of the tourism industry to welcome visitors at the present time. It can be said that hotels have been contributing to affirm the brand, professionalism, and service quality according to the national standards, in particular, and the quality and image of Thanh Hoa tourism, in general. In addition, it helps to create confidence for customers when choosing hotels that have been recognized by the competent State agencies. Because of its important role, the quality of accommodation will directly affect the quality of tourism, as well as the image of friendly, civilized destination that Thanh Hoa tourism is aiming for.

The final target of a firm in doing business is increasing customer satisfaction by serving their demands as well as because customer satisfaction may lead to their loyalty, so that it is one of the most important factors which can help to increase a firm's business sales. Meanwhile, customers will feel satisfied by the valuable and qualified services provided by enterprises that bring them the impressive image. Destination image is considered to be one of the most important factors to attract tourists. An attractive destination image can promote the tourist's experience and lead to customer's satisfaction that may encourage tourists to return (Lee \& Syah, 2018). Therefore, with the target of assessing the overall service quality, destination image, and customer satisfaction using hotel services in Thanh Hoa province, this article aims at identifying the main factors affecting customer satisfaction in Thanh Hoa province and the influence level of each factor. Theoretically, research on customer satisfaction in the world is abundant, but in the field of hotel industry in Thanh Hoa province, is very little. With a preliminary view on some characteristics and limitations of hotel business in the area, as well as the lack of related studies about hotels' customer satisfaction in Thanh Hoa province, this research is necessary, in a practical basis, in the current context of Vietnam.

\section{Literature Review and Research Model}

\subsection{Customer Satisfaction}

Customer satisfaction is the customer's evaluation after use of the service (Hunt, 1977; Mostafa, 2005). It is an effective attribute of emotional response through which customers know their needs and expectations in the process of using the service that have been met. Customer satisfaction is the subjective judgment that a customer bases on his or her knowledge on a product or service. It is a kind of psychological feeling after the fulfillment of their needs provided by the firms. Customer satisfaction is important because it affects the long-term growth of profitability (Ribbink et al., 2004). Satisfied customers are the best customers, because they rarely save money, but often pay more than other customers, and advertise for products and services effectively by verbal mean.

\subsection{Determinants of Customer Satisfaction}

The measurement of customer satisfaction has attracted many researcher from years. The similarities and differences in customer satisfaction between the Asian and Western tourists have been highlighted based on the studies by Wai and Kevin (2005). According to the authors, the hospitality factor is the most influential factor in determining customer satisfaction for both Asian and Western tourists. Asian travellers are more interested in value, while Western travellers are more concerned about security and safety. Orthodox and Krishna (2016), in their research on the relationships between hotel ratings, service quality, customer satisfaction and loyalty at Ethiopian hotels concluded that there are significant relationships between these concepts. Customer satisfaction depends not only on the ratings of hotels, but also relies heavily on the quality of hotel services, which provide positive value perception to customers (Kofi et al., 2013).

A study of the tourism services quality in Egypt concluded that customer satisfaction depended on tourism services, levels of hotel services, value related to services' prices, accommodations, internal transportation, and suitable prices (Eraqi, 2006). Study of customer satisfaction in Pakistan agreed on the point that service quality and service features played an important role in augmenting satisfaction (Abbasi et al., 2010). In Vietnam, the research about the effects of factors on guests' satisfaction and loyalty to luxury hotels in Ho Chi Minh City conducted a quantitative approach method with 255 questionnaire directly delivered to tourists staying at 3-5-star hotels. The results showed that proposed factors as empathy and assurance, tangibility and hotel image, which directly affected customers' satisfaction (Mai et al., 2015). A recent study by Nguyen et al. (2020) showed that among various determinants, service capacity and tangibility have the strongest impact on customer satisfaction. Research results from 500 tourists in the mountain destinations of Thanh Hoa province demonstrated that all factors constituting a destination image, including natural features, resources, infrastructure, government support, perceived price, and human factors, have a positive impact on tourist satisfaction (Le \& Le, 2020).

\subsection{Proposed Research Model}

Through many studies, in each approach and viewpoint of the researchers, many factors have been shown to have a direct or indirect impact on customer satisfaction using hotel services. However, many authors have studied the common factors such as service quality and price. Other authors have found out that factors of brand image and CRM do have an important impact on customers' satisfaction. This difference is due to the models that include the proposed factors affecting customer satisfaction are wide-ranging and are considered in different aspects, 
different customers, and different cultures. Therefore, the determination of the factors affecting the satisfaction of hotel industry are only relative and can vary based on space and time. Based on the overview of the literature and studies, along with the analysis and assessment of the actual performance of 3-5star hotel businesses in Thanh Hoa province, and consultation with major hotel business owners and managers, and experts in the field of the hospitality industry, the researchers found that factors such as perceived quality (including both tangibles' perception and intangibles' perception) (Drazen et al., 2016), perceived value, brand and customer relationship management (CRM) affect the satisfaction of customers using hotel services in Thanh Hoa province.

The relationship between factors as perceived quality, perceived value, brand image, and customer relationship management with customer satisfaction is very complex. However, this study has considered the relationship between five independent factors: perceived quality (tangible and intangible), perceived value, brand image, customer relationship management (CRM), and customer satisfaction factor (dependent factor) as shown in Figure 1. The researchers also proposed the impact of some demographic characteristics such as gender, nationality, income, age, education level, and duration to the satisfaction of customers using hotels in Thanh Hoa province. Hypotheses are as follows:

H1: Tangible elements have significant influence (+) on customer satisfaction

H2: Intangibles elements have significant influence (+) on customer satisfaction.

H3: Perceived value has significant influence (+) on customer satisfaction.

H4: Brand image has significant influence (+) on customer satisfaction.

H5: Customer relationship management has significant influence (+) on customer satisfaction.

H6: There is a difference in satisfaction among customers in term of demographic characteristics (gender, nationality, age, educational level, monthly income, duration).

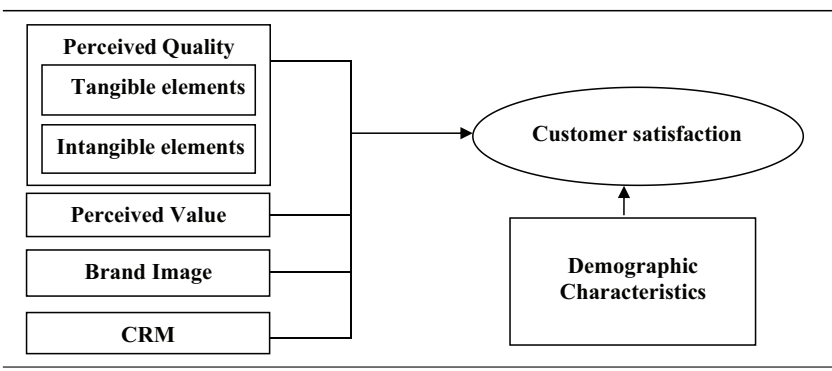

Figure 1: Proposed Research Model

\section{Research Method}

\subsection{Subject of the Study}

Subjects of the study are the factors affecting customer satisfaction in hotels with a minimum of 50 rooms, which have been classified as 3-5 star hotels by the National Administration of Tourism in Thanh Hoa province. The researchers choose to study 3-5-star hotels because these medium and luxury hotels are the common choice of both domestic and international tourists due to the appropriate service quality. According to statistics of Vietnam National Administration of Tourism, the majority of international visitors to Vietnam choose hotels with 3-4 star or more and domestic guests prefer 3-star hotels because their services just can meet the tourists' basic needs in conditions of improved material and spiritual life ${ }^{\mathrm{i}}$.

Quantitative research was conducted based on the sampling survey of 500 respondents in 13 hotels which were rated as 3-5 stars hotels in Thanh Hoa province, located in three districts - Thanh Hoa City (six hotels), Sam Son City (six hotels), and Tinh Gia (one hotel).

\subsection{Sampling Technique}

The researchers used quota sampling technique to divide the number of questionnaires required for 13 hotels, and then continued to use the convenient sampling method to select the customers whom the researcher can approach. The balanced stratified sampling method was used so that the number of subjects selected from each hotel is calculated proportionally to the room scale of each hotel.

Respondents answering questionnaires need to meet the following criteria: (1) be over 18 years old; (2) have used the services of any of the 13 3-5 star hotels in the last six months because their experiences remained fresh in their memory and it is easy to recall them and appreciate the experience about hotel service. The survey was done in two forms: direct questionnaires, which was the main form of survey, and e-mail surveys via the email address of the respondents supplied by the hotels.

The method of determining the sample size in the research followed the determination of the sample size by Hair et al. (1998). The sample size was determined based on minimum and variable quantities included in the analysis of the model, where the minimum is usually 50-100. The author proposed a 5:1 ratio for sample size selection versus the number of parameters in the multivariate analysis. The model in this research identified 31 observations, using the 5-point Likert scale. The original sample size was $31 * 5=155$. Excluding ineligible questionnaires, the researchers decided to settle on 500 questionnaires, distributed to 13 3-5-star hotels. 


\subsection{Scale Development}

In the scope of this research, the scale was built on the basis of the theory of satisfaction by Parasuraman et al. (1988) and service quality model by Gronross (1984). The scales were modified and supplemented to suit research purposes referenced from other researchers in this field.

(i) Scale of "Perceived Quality": Consumer satisfaction in perceived service quality measured by the overall assessment of consumers about their belief in hotel service quality, both about tangibles and intangible elements. The measurement scale was inherited from research by Drazen et al. (2016); Orthodox and Krishna (2014).

(ii) Scale of "Perceived Value": Perception of price for hotel services (referred to as value perception) is a measure of how consumers are aware of the price of service provided by the hotel; if they think that the services are worth or not. Measurement scale was inherited from Le (2017).

(iii) Scale of "Brand Image": Consumer awareness in brand (referred to brand image) is measured by the overall feelings of customers about brand of the hotel, including the easy awareness, impression, remembering, and priority. Measurement scale was inherited from research from So et al., 2013).

(iv) Scale of "Customer Relationship Management CRM": The CRM is a measure of how the hotel strives to create a good relationship and keep the connection with customers. The scale was derived from Nguyen et al. (2007).

(v) Scale of "Customer Satisfaction": The scale of customer satisfaction inherited from Le \& Nguyen (2007); Le \&Le (2020); Kofi et al. (2013).

\subsection{Analysis Method}

Quantitative research aims to quantify the relationship between factors through the application of statistical analysis tools SPSS 20 (Dinh, 2013). Data collected after being encrypted was cleaned and examined with reliability, exploratory factor analysis (EFA), correlation, regression and Anova tests.

\section{Results and Discussion}

\subsection{Findings}

\subsubsection{Descriptive Statistics}

The response rate of the survey was 340 hard copies (of which two were invalid due to the lack of information, accounting for $89 \%$ of the valid responses) and 42 valid online questionnaires (accounting for $11 \%$ ). So, the total valid sample size was 380 . The information of the respondents is displayed in Table 2.

The descriptive results show that customer item ratings are in the range of Fair to Good. The highest average value is the hotels' tangible element (3.53) and the lowest values are intangible elements (3.37), customer satisfaction (3.39) and customer relationship management (3.4). In terms of the tangible facilities of hotels, customers appreciate the availability and the full range of equipment and additional services, owing to the fact that the 3-5-star hotels in Thanh Hoa province are almost new, which were built in the last five years, especially 7 out of 13 hotels were built in 2015 (the year of national tourism in Thanh Hoa province). In term of intangible elements, customers only evaluated these factors at the medium level. Of which, statements 'Customers are always fully provided with information about the services of the hotel' (3.25), 'Hotel staff is knowledgeable about the service that the hotel offers' (3.31), and 'The staff of the hotel gives the customer confidence' (3.34) are not highly appreciated by customers.

About the perceived value elements, customer reviews are relatively good about the hotel service prices, which are competitive and correspond to the quality of service provided by the hotels. Elements brand image of hotels was not rated well by customers, the average value is between 3.33 and 3.53. This shows that 3-to-5-star hotels in Thanh Hoa, especially new hotels, need to make more efforts to bring brand image closer to customers, who are using their service. In general, customers are fairly satisfied with the services that 3-to-5-star hotels in Thanh Hoa are providing.

Table 1: Scale development source

\begin{tabular}{|l|l|l|l|}
\hline Variable Code & \multicolumn{1}{|c|}{ Factor } & \multicolumn{1}{c|}{ Authors } & \multicolumn{1}{c|}{ Research variables } \\
\hline $\begin{array}{l}\text { TAG } \\
\text { INTAG }\end{array}$ & Perceived Quality & $\begin{array}{l}\text { Drazen, Veljko, Radenko and Darko } \\
(2016) ; \text { Orthodox \& Krishna (2014). }\end{array}$ & Tangible and Intangible elements \\
\hline VALUE & Perceived Value & Le (2017) & Perceived Value \\
\hline BRA & Brand Image & So, King, Sparks, Wang (2013) & Brand Image \\
\hline CRM & CRM & Nguyen, Sherif and Newby (2007). & CRM \\
\hline SATIS & Satisfaction & $\begin{array}{l}\text { Le and Nguyen (2007); Le and Le (2020); } \\
\text { Kofi, Mariama and Ajaza (2013). }\end{array}$ & Satisfaction \\
\hline
\end{tabular}


Quang Hieu LE, Thanh Xuan Thi NGUYEN, Thanh Thuy Thi LE /

Table 2: Descriptive statistics of the respondents

\begin{tabular}{|c|c|c|c|c|c|c|c|c|}
\hline \multicolumn{2}{|c|}{ Respondents } & \multirow{2}{*}{$\frac{\text { Frequency }}{243}$} & \multicolumn{2}{|c|}{ Respondents } & Frequency & \multicolumn{2}{|c|}{ Respondents } & Frequency \\
\hline \multirow{3}{*}{ Gender } & Male & & \multirow{14}{*}{$\begin{array}{l}\text { Hotel } \\
\text { name }\end{array}$} & Lam Kinh & 54 & \multirow{3}{*}{ Purpose } & Job related & 153 \\
\hline & Female & 137 & & Thien $Y$ & 47 & & Entertain & 227 \\
\hline & Total & 380 & & Muong Thanh & 51 & & Total & 380 \\
\hline \multirow{3}{*}{ Nationality } & Vietnamese & 251 & & Anh Phat 2 & 20 & \multirow{4}{*}{$\begin{array}{l}\text { Type of } \\
\text { hotel }\end{array}$} & 3 stars & 151 \\
\hline & Foreigner & 129 & & Sao Mai & 25 & & 4 stars & 204 \\
\hline & Total & 380 & & Phu Dong & 26 & & 5 stars & 25 \\
\hline \multirow{4}{*}{$\begin{array}{l}\text { Educational } \\
\text { level }\end{array}$} & Post graduate & 57 & & Phonenix & 20 & & Total & 380 \\
\hline & Bachelor & 198 & & Bien Nho & 20 & \multirow{7}{*}{$\begin{array}{l}\text { Information } \\
\text { channel }\end{array}$} & Relative & 126 \\
\hline & Lower & 125 & & VDB & 20 & & Website & 114 \\
\hline & Total & 380 & & Van Chai & 21 & & Business & 41 \\
\hline \multirow{6}{*}{ Occupation } & Employed & 180 & & Viet Hung & 20 & & Telephone & 23 \\
\hline & Self-employed & 106 & & Dragon Sea & 31 & & Brochure & 38 \\
\hline & Unemployed & 39 & & FLC SS & 25 & & Different & 38 \\
\hline & Students & 49 & & Total & 380 & & Total & 380 \\
\hline & Different & 6 & \multirow{6}{*}{ Duration } & 1 night & 104 & \multirow{6}{*}{$\begin{array}{l}\text { Service } \\
\text { Forms }\end{array}$} & Entire of & 105 \\
\hline & Total & 380 & & 2-4 nights & 118 & & service & 195 \\
\hline \multirow{4}{*}{$\begin{array}{l}\text { Monthly } \\
\text { income }\end{array}$} & $<5$ mil VND & 38 & & 5-7 nights & 50 & & & \\
\hline & 5-10 mil VND & 153 & & 7 a int & & & Part OT & 185 \\
\hline & $>10 \mathrm{mil} \mathrm{VND}$ & 189 & & $>r$ nignts & 100 & & & \\
\hline & Total & 380 & & Total & 380 & & Total & 380 \\
\hline
\end{tabular}

This is a sign that the hotels have not achieved positive effects in providing services to their customers. Moreover, the hotels must attend to some constraints such as customer relationship service and factors about their staff for the improvement of their service quality in the future.

\subsubsection{Exploratory Factor Analysis - EFA}

After the first EFA for independent variables, TAG6 and BRA4 variables were excluded. The study conducted the second EFA for 22 items, except for TAG6 and BRA4 variables; the KMO test results of the second rotation showed that the KMO and Bartlett's test showed: $\mathrm{KMO}=$ $.824(0.5<=\mathrm{KMO}<=1)$; Bartlett's test statistic $=3392.354$ with Sig $=0.00<0.05$, which means that the application of Exploratory Factor Analysis in the study is appropriate. Moreover, factors have the Eigenvalue $>1$, which is greater than $50 \%(62.096 \%)$ of the variables; the observed variables are grouped exactly as the initial scale. After the analysis of EFA, the model is not different from the proposed model excepted for TAG6 and BRA4 variables.

\subsubsection{Reliability of the Scale}

Table 4 shows the test reliability of the scale after EFA step. The result shows that the scales both have a reasonably strong Cronbach's Alpha coefficient and the Corrected item - Total correlation of items are all more than 0.3. Thus, the proposed items measure the same concepts and the scales are realiable for using in the next steps.

\subsubsection{Correlation Analysis}

According to the results, variables are correlated with the dependent variable and statistically significant. The most strongly correlated with the dependent variable was TAG $(0.510$, with $\mathrm{p}<0.05)$ and the weakest correlation was the CRM factor $(0.379$, with $\mathrm{p}<0.05)$. The results mean that the elements tangible elements, intangible elements, perceived value, brand image, and customer relationship management have a significant impact on satisfation. 
Table 3: Rotated Component Matrix

\begin{tabular}{|c|c|c|c|c|c|c|}
\hline \multirow{2}{*}{ Factor } & & \multicolumn{5}{|c|}{ Factor } \\
\hline & & 1 & 2 & 3 & 4 & 5 \\
\hline INTAG4 & Hotel staffs are well knowledgeable about services & .853 & & & & \\
\hline INTAG2 & The assurance of safety is made by hotels' staffs & .789 & & & & \\
\hline INTAG5 & The staff of the hotel gives the customer confidence & .743 & & & & \\
\hline INTAG3 & The staff of the hotel is very enthusiastic and friendly & .700 & & & & \\
\hline INTAG6 & The hotel has provided the right service as promised & .604 & & & & \\
\hline INTAG1 & Customers are always fully provided with information & .567 & & & & \\
\hline TAG2 & The hotel has full of facilities for clients & & .845 & & & \\
\hline TAG4 & Availability of added services & & .734 & & & \\
\hline TAG3 & The good physical features of the hotel & & .723 & & & \\
\hline TAG1 & The hotel have modern equipments & & .570 & & & \\
\hline TAG5 & The attractiveness of the lobby area & & .563 & & & \\
\hline CRM2 & Hotel has quick and convenient service procedures & & & .854 & & \\
\hline CRM1 & $\begin{array}{l}\text { Hotel provides service in line with customer's demand and } \\
\text { personalization }\end{array}$ & & & .796 & & \\
\hline CRM3 & Hotel has small souvenir for guests & & & .583 & & \\
\hline CRM5 & Good customer information security system & & & .556 & & \\
\hline CRM4 & Hotel staff always call to inquire about the satisfaction & & & .519 & & \\
\hline VALUE2 & Price corresponds to the quality of service & & & & .777 & \\
\hline VALUE1 & Hotel services prices are competitive & & & & .735 & \\
\hline VALUE3 & The prices of hotel services are diversified & & & & .609 & \\
\hline BRA2 & The brand of the hotel impresses customers & & & & & .769 \\
\hline BRA1 & The hotel brand is easily recognizable & & & & & .565 \\
\hline BRA3 & I easily imagine its characteristics & & & & & .527 \\
\hline
\end{tabular}

Table 4: Results of Cronbach's Alpha Test

\begin{tabular}{|l|l|c|c|}
\hline No & Factors & $\begin{array}{c}\text { Number of } \\
\text { variables }\end{array}$ & $\begin{array}{c}\text { Cronbach's } \\
\text { Alpha }\end{array}$ \\
\hline 1 & Tangible elements & 5 & 0.841 \\
\hline 2 & Intangible elements & 6 & 0.870 \\
\hline 3 & Perceived Value & 3 & 0.771 \\
\hline 4 & Brand Image & 3 & 0.689 \\
\hline 5 & CRM & 5 & 0.805 \\
\hline 6 & Satisfaction & 7 & 0.839 \\
\hline
\end{tabular}

\subsubsection{Regression Analysis}

To assess the impact of each factor on the customer satisfaction at the hotel, the author uses a multivariable regression model. The result of the F-test assesses the suitability of the overall linear regression model, whether the dependent variable is linearly related to the total independent variable. Test $\mathrm{F}$ shows the significance level Sig. (Very small; Sig. $=0.000$ ) and $\mathrm{R}^{2}=0.522$ (Adjusted $\mathrm{R}^{2}$ $=0.515)$ demonstrates the suitability of the model, which is more than $50 \%$ of service satisfaction was explained by five independent variables. The Durbin-Watson coefficient = $1.713(>1)$ indicates that there is no autocorrelation between variables. 
Quang Hieu LE, Thanh Xuan Thi NGUYEN, Thanh Thuy Thi LE /

Journal of Asian Finance, Economics and Business Vol 7 No 10 (2020) 919-927

Table 5: Results of hypothesis test

\begin{tabular}{|l|c|c|c|c|c|c|}
\hline \multicolumn{2}{|c|}{} & Standardized Beta & Sig & Hypothesis & Results \\
\hline SATIS & $<---$ & TAG & .259 & .000 & H1 & Accepted \\
\hline SATIS & $<---$ & INTAG & .271 & .000 & H2 & Accepted \\
\hline SATIS & $<---$ & VALUE & .193 & .000 & H3 & Accepted \\
\hline SATIS & $<---$ & BRA & .251 & .000 & H4 & Accepted \\
\hline SATIS & $<---$ & CRM & .169 & .000 & H5 & Accepted \\
\hline
\end{tabular}

All independent variables have significant value less than 0.05. All independent factors affect customer satisfaction of the hotels. The importance of each factor depends on the standardized Beta (in terms of the absolute value of the factor). Whatever factor has a larger standardized Beta factor has a stronger impact on hotel satisfaction. The results of multiple regression analysis showed the importance of each factor, which depended on the standardized Beta as following:

$$
\begin{aligned}
\text { SATIS } & =0.271 * \text { INTAG }+0.259 * \text { TAG }+0.193 * \text { VALUE } \\
& +0.251 * \text { BRA }+0.169 * \mathrm{CRM}
\end{aligned}
$$

The results mean that tangible elements, intangible elements, perceived value, brand image, customer relationship management have a positive impact on satisfation. The impact level of each factor are as order: intangible $(\beta=0.271)$; tangible $(\beta=0.259)$; brand image $(\beta=0.251)$; perceived value $(\beta=0.193)$; customer relationship management $(\beta=0.169)$. Hypotheses H1, H2, H3, H4, H5 are accepted.

The differences in term of demographic variables after T-test and Anova testing also revealed that foreigners, higher education customers and over-7-day-staying customers tend to be more satisfied with the hotels than the others, which may suggest important and appropriate solutions for hotels in Thanh Hoa province for this market share.

\subsection{Discussion}

In the Thanh Hoa province market, according to descriptive statistics, the satisfaction of customers with the hotels' brand is fair. This can be explained by the fact that there are many 3-5-star hotel brands competing in Thanh Hoa market. However, the hotels mostly have been newly built in recent years, so they have not yet built a strong brand image. Because of the new operation, the facilities and equipment of the hotels now are very new and modern. However, in the future, hotels must have a better strategy to upgrade and replace old facilities and equipment because technology must be continually updated. In terms of human resource quality, through statistics, it can be found that the number of unskilled staffs is high, especially in some hotels, where unskilled workers account for one-third or even a half of the workforce. Customers also did not high appreciate the serving from hotels' staffs. This is a great challenge for tourism businesses in particular and hotel business in Thanh Hoa province in general.

The results of the regression analysis show that tangible and intangible elements of service quality, perceived value, brand image, customer relationship management have a positive impact on Satisfaction, of which the strongest influence is intangible; tangible; brand image; perceived value; customer relationship management. The results of this study are consistent with previous research findings in the service sector, particularly hotel services: tangible and intangible elements of service quality, value, brand image, and customer relations are mutually connected (Liang, 2008; Le \& Nguyen, 2007; Taylor et al., 2004; Le, 2017). At the same time, service quality is the most important factor influencing customers' satisfaction.

There is, however, no difference between the levels of satisfaction of the respondents based on different gender, age, and income. There is a difference between Vietnamese and foreign customers, whereby foreign customers tend to be more satisfied with the hotels they are using than local customers, which is explained by the difference on culture leading to difference in consumer behavior (Akaba, 2013). On the other hand, foreign customers have less information about the hotels in the locality than Vietnamese; moreover, the language barrier and the inconvenience in changing accommodation tends to make the foreign customers more loyal to the hotels they are using. As a result, hotels with more foreign customers should pay attention to this point so that they can create the impression and satisfaction for foreign customers because they have the more satisfied consumption trend.

In addition, there is the difference in satisfaction of educational level and duration groups. According to the test results, the satisfaction of group with post-graduate degree education and groups with duration of staying longer than 7 days are higher than the other two groups. This can be 
explained by the fact that foreign experts, who are working in the Nghi Son economic zone in Thanh Hoa Province, possess advanced degrees, who mainly stay over than 7 days in some 3-5-star hotels in Thanh Hoa during their work. This is a higher level group of customer satisfaction, matching the test of difference between Vietnamese and foreign customer groups whereby foreign clients (most of who are professionals in the Nghi Son Economic Zone and possess high degrees) are more satisfied and loyal than other groups of customers.

\section{Conclusion and Limitation}

The research has systematized the theoretical basis for the factors affecting the service quality and customer satisfaction using the service provided by the hotels. Based on the related studies in the field of hotel services, this research has proposed five factors that affect satisfaction of customers using 3-to-5-star hotel services in Thanh Hoa province. The research has demonstrated the influence of tangible, intangible elements, perceived value, brand image and customer relationship management to customer satisfaction. In particular, the confirmation that the customer relationship management factor has a positive impact on the satisfaction of customers is a clear evidence that the hotel business in Thanh Hoa should focus on attracting previous customers returning to use the service through a customer relation strategy. In addition, the study found that foreign customers and high educational level customers tend to be more satisfied with the hotels than the other, which may suggest important and appropriate solutions for hotels in Thanh Hoa province for this market share.

Based on the research results, in order to improve customer satisfaction, 3-to-5-star hotels in Thanh Hoa province should focus on improving service quality as it is the strongest factor impacting on customer's adjustment. On the other hand, to improve satisfaction, it is necessary to improve tangible elements such as facilities, equipment, and availability of complementary services such as swimming pools, gyms, and saunas. The other important factor to focus on is the improvement of human resources through the provision of short-term and long-term training programs, the process of recruiting, using and educating hotel staff so that they can provide customers with the most complete, timely, and accurate information on the services provided by the hotels, to be the best assistant to each customer and to create a good impression in customers' perception. In addition, in term of the pricing strategy, hotel businesses need to set competitive and diversified prices to meet the needs of customers, improve brand image through promotion strategy, diversify and differentiate strategy to connect with new customers, but still retain old customers through an effective CRM strategy.
Although the research has met the initial objectives to find the influence of factors on the satisfaction of customers in Thanh Hoa province, due to many subjective and objective reasons, the research cannot avoid some limitations. Firstly, the research sample, compared to the number of hotels in Thanh Hoa, is not big. On the other hand, the research has only assessed the impact of factors in 3-to-5-star hotels at one destination, Thanh Hoa province, a place that has many differences compared to other localities in terms of natural conditions, economic conditions, population, and society; thus, the results of the study may differ from other localities in the country. Therefore, further studies should be performed on more diversified types of hotels, on a larger sample scale, and within a larger geographical area, thus, enhancing the overall scope of the subject. Lastly, in the following models, researchers can integrate other internal factors (such as corporate strategy) and external factors (such as local economic development and local tourism policies) to test more hypotheses with more factors affecting customer satisfaction.

\section{References}

Abbasi, A.S., Khalid, W., Azam, M., \& Riaz, A. (2010). Determinants of Customer Satisfaction in Hotel Industry of Pakistan. European Journal of Scientific Research, 48(1), 97-105.

Dinh, P. H. (2013). Economic Research Methodology and master thesis writing. Ho Chi Minh City, Vietnam: Economic Publishing House

Drazen, M., Veljko, M., Radenko, M., \& Darko, D. (2016). Analysis of tangible and intangible hotel service quality components. Industrija, 44(1), 7-25.

Eraqi, M. I. (2006). Tourism services quality in Egypt: The viewpoints of external and internal customers Benchmarking. An International Journal, 13(4), 469-492.

Gronroos, C. (1984). A service quality model and its marketing implications. European Journal of Marketing, 18(4), 36-44.

Hair, J. F., Black, W. C., Babin, B. J., Anderson, R. E., \& Tatham, R. L. (1998). Multivariate data analysis. Upper Saddle River, NJ: Prentice Hall

Hunt, K. H. (1977). Conceptualization and measurement of consumer satisfaction and dissatisfaction (pp. 77-103). Cambridge, MA: Marketing Science Institute.

Kofi, P., Mariama, Z., \& Ajaza, S. (2013). Impact of Service Quality on Customer Loyalty in the Hotel Industry: An Empirical Study from Ghana. International Review of Management and Business Research, 2(2), 600-609.

Le, H. B. H., \& Le, T. B. (2020). Impact of Destination Image and Satisfaction on Tourist Loyalty: Mountain Destinations in Thanh Hoa Province, Vietnam. Journal of Asian Finance, Economics and Business, 7(4), 185-195. https://doi. org/10.13106/jafeb.2020.vol7.no4.185 
Le, T. B. (2017). The impact of the quality of tourism services, the price perception to satisfaction and loyalty of visitors to destinations in Thanh Hoa province. Journal of Economics and Development, 242(2), 91-101.

Le, V. H., \& Nguyen, T. H. M. (2007). Develop a theoretical model and measurement method for the Customer Satisfaction Index in Vietnam. Banking Journal, 12, 5-10.

Lee, J. W., \& Syah, A. M. (2018). Economic and environmental impacts of mass tourism on regional tourism destinations in Indonesia. Journal of Asian Finance, Economics and Business, 5(3), 31-41. http://doi.org/10.13106/jafeb.2018. vol5.no3.31

Liang, D. (2008). The determining factors of customer loyalty for Luxury hotels in US. The Journal of International Management Studies, 3(2), 167-175.

Mai, N. K., Pham, L. H. N., \& Nguyen, T. M. P. (2015). Factors of affecting guests' satisfaction and their loyalty - A study of Luxury hotels in Ho Chi Minh City, Vietnam. International Journal of Innovation, Management and Technology, 6(3), 186-190.

Mostafa, M. (2005). An empirical study of patients' expectations and satisfactions in Egyptian hospitals. International Journal of Health Care Quality Assurance, 18(7), 516-532

Nguyen, D. T., Pham, V. T., Tran, D. M., \& Pham, D. B. (2020). Impact of Service Quality, Customer Satisfaction and Switching Costs on Customer Loyalty. Journal of Asian Finance, Economics and Business, 7(8), 395-405. http:/doi:10.13106/ jafeb.2020.vol7.no8.395

Nguyen, T. H., Sherif, J. S., \& Newby, M. (2007). Strategies for successful CRM implementation. Information Management \& Computer Security, 15(2), 102-115
Orthodox, T., \& Krishna, G. (2014). Hotel ratings, service quality, customer satisfaction and loyalty: The perception of guests at Ethiopian Hotels. African Journal of Hospitality, Tourism and Leisure, 5(3), 1-18.

Parasuraman, A., Zeithaml, V., \& Berry, L. (1988). SERVQUAL: A multiple- Item Scale for measuring consumer perceptions of service quality. Journal of Retailing, 64(2), 12-40

Ribbink, D., Riel, A. C. R. V., Liljander, V., \& Streukens, S. (2004). Comfort your online customer: quality, trust and loyalty on the internet. Managing Service Quality, 14(6), 446-644.

So, K., King, C., Sparks, B., \& Wang, Y. (2013). The influence of customer brand identification on hotel brand evaluation and loyalty development. International Journal of Hospitality Management, 34, 31-41

Taylor, S., Kevin, C., \& Stephen, G. (2004). The importance of brand equity to customer loyalty. Journal of Product \& Brand Management, 13(4), 109-120. doi: 10.1108/10610420410546934

Wai, C. P., \& Kevin L. L. (2005), Are travellers satisfied with Malaysian hotels? International Journal of Contemporary Hospitality Management, 17(3), 217-227.

Zeithaml, V. A., Berry, L., \& Parasuraman, A. (1996). The Behavioral Consequences of Service Quality. Journal of Marketing Management, 60, 31-46.

\section{Endnote}

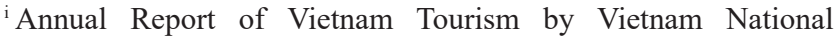
Administration of Tourism in 2014, 2015. 